\title{
A Predictive Model for Avoiding Follow-Up Paracentesis in Spontaneous Bacterial Peritonitis
}

\author{
Ana Luísa Santos ${ }^{a, b}, c$ Rosa Coelho ${ }^{a, b}, c$ Marco Silva ${ }^{a, b}, c$ Rui Morais ${ }^{a, b}, c$ \\ Hélder Cardoso ${ }^{a, b, c}$ Guilherme Macedo ${ }^{a, b, c}$ \\ ${ }^{a}$ Gastroenterology Department, Centro Hospitalar Universitário de São João, São João, Portugal; b Porto Medical \\ School, Porto, Portugal; ' WGO Porto Training Center, Porto, Portugal
}

\section{Keywords}

Spontaneous bacterial peritonitis · Liver · Cirrhosis ·

Antibiotics · Paracentesis

\section{Abstract}

Background: Recent studies suggest that follow-up paracentesis (FuP) in cases of spontaneous bacterial peritonitis (SBP) should only be performed if there is a clinical and/or analytic worsening. We aimed to evaluate which patients with SBP would benefit from the FuP. Métodos: This retrospective study included consecutive patients diagnosed with SBP between January 2011 and June 2018 in our tertiary center. Clinical and analytical data were obtained at baseline and on the third day of antibiotic therapy. An adequate response on the third day of treatment was defined by a decrease of $\geq 25 \%$ in the neutrophil count of the ascitic fluid (AF). Results: Ninetysix episodes of PBE in 75 patients (79\% male sex, mean age $61 \pm 11$ years old) were included. At admission, a higher serum neutrophil count ( $p=0.043)$, a lower level of serum total proteins $(p=0.040)$, a positive culture in AF $(p<0.001)$ and a previous diagnosis of diabetes mellitus $(p=0.035)$ were related to inadequate response (IR). At day 3 , acute kidney injury ( $p=0.023), C$-reactive protein $>100 \mathrm{mg} / \mathrm{L}(p<0.001)$, the presence of fever $(p=0.047)$ and abdominal pain $(p<0.001)$ were also associated with IR. In multivariate analysis, the presence of respiratory insufficiency $(\mathrm{OR}=16.403 ; 95 \% \mathrm{Cl}$ :
2.315-116.222; $p=0.005)$ and abdominal pain (OR = 10.381; 95\% Cl: 1.807-59.626; $p=0.009)$ at admission, serum white blood cell count $>9 \times 10^{9}(\mathrm{OR}=5.832 ; 95 \% \mathrm{Cl}$ : $1.275-26.669$; $p=0.023)$, and CRP $>100 \mathrm{mg} / \mathrm{L}(\mathrm{OR}=5.043$; $95 \% \mathrm{Cl}: 1.267-$ $20.076 ; p=0.022$ ) at day 3 of antibiotic therapy were predictors of IR. The predictive model presented good accuracy [AUROC of $0.893(p<0.001)$ ] - a cutoff of 0.090 had a sensitivity, specificity, positive predictive value, and negative predictive value for IR of 97, 46, 83, and 77\%, respectively. Conclusions: The performance of FuP on day 3 after the beginning of empiric therapy should be individualized, according to clinical and analytic variables of this predictive model.

(C) 2021 Sociedade Portuguesa de Gastrenterologia Published by S. Karger AG, Basel

\section{Modelo preditivo para evitar a paracentese de seguimento na peritonite bacteriana espontânea}

\section{Palavras Chave \\ Peritonite bacteriana espontânea · Fígado · Cirrose hepatica · Antibioterapia · Paracentese}

\section{Resumo}

Introdução: Estudos recentes têm sugerido a realização de paracentese de seguimento ao $3^{\circ} \mathrm{dia}$, na peritonite karger@karger.com www.karger.com/pjg

Karger $\stackrel{\text { ' }}{5}$

BOPEN ACCESS
(C) 2021 Sociedade Portuguesa de Gastrenterologia. Published by S. Karger AG, Basel

This is an Open Access article licensed under the Creative Commons Attribution-NonCommercial-4.0 International License (CC BY-NC) (http://www.karger.com/Services/OpenAccessLicense), applicable to the online version of the article only. Usage and distribution for commercial purposes requires written permission.
Correspondence to:

Ana Luísa Santos, anaasantos89@gmail.com 
bacteriana espontânea (PBE), apenas em doentes com agravamento clínico e/ou analítico. Este trabalho pretende avaliar quais os doentes em que a paracenteses ao $3^{\circ}$ dia se mantém essencial. Methods: Estudo retrospetivo realizado em centro terciário, com inclusão dos doentes com PBE entre janeiro de 2011 e junho de 2018. Dados clínicos e analíticos foram obtidos à data de admissão e ao $3^{\circ}$ dia de antibioterapia. A resposta terapêutica foi considerada adequada quando a contagem de neutrófilos no líquido ascítico era $\geq 25 \%$. Resultados: Foram incluídos 96 episódios de PBE correspondentes a 75 doentes (79\% homens, com idade media de $61 \pm 11$ anos). À admissão, a presença de diabetes mellitus ( $p=0.035)$, uma maior contagem de neurófilos séricos $(p=0.043)$, nível inferior de proteínas séricas totais $(p=0.040)$ e positividade nas culturas de líquido ascítico total $(p<0.001)$ relacionaram-se com inadequada resposta (IR). Ao $3^{\circ}$ dia de antibioterapia, a presença de lesão renal aguda $(p=0.023)$, proteína $C$ reativa $>100 \mathrm{mg} / \mathrm{L}(p<0.001)$, febre $(p=0.047)$ e dor abdominal $(p<0.001)$ foram também associados a IR. Na análise multivariada, a presença de insuficiência respiratória $(\mathrm{OR}=16.403 ; 95 \% \mathrm{Cl}: 2.315-116.222 ; p=0.005)$ e dor abdominal $(\mathrm{OR}=10.381 ; 95 \% \mathrm{Cl}: 1.807-59.626 ; p=0.009)$ à admissão, contagem séria de leucócitos $>9 \times 10^{9}(\mathrm{OR}=$ 5.832; $95 \%$ Cl: $1.275-26.669 ; p=0.023)$ e PCR $>100 \mathrm{mg} / \mathrm{L}$ $(\mathrm{OR}=5.043 ; 95 \% \mathrm{Cl}: 1.267-20.076 ; p=0.022)$ ao $3^{\circ} \mathrm{dia}$ de antibioterapia foram preditores de IR. O modelo preditivo apresentado apresenta boa acuidade [AUROC de 0.893 ( $p$ $<0.001)$ ] - para um cutoff de 0.090 tem uma sensibilidade, especificidade, valor preditivo positivo e valor preditivo negativo para IR de $97,46,83$, e $77 \%$, respetivamente. Conclusões: De acordo com o nosso modelo, a realização de paracenteses de seguimento ao 3 dia após início de antibioterapia empírica deverá ser individualizada, de segundo as variáveis clínicas e analíticas apresentadas.

(C) 2021 Sociedade Portuguesa de Gastrenterologia Publicado por S. Karger AG, Basel

\section{Introduction}

In its decompensated state or with portal hypertension, liver cirrhosis is associated with significant changes in the human immune system leading to a syndrome called cirrhosis-associated immune dysfunction [1]. This dysfunction, related to the increase in intestinal permeability, results in bacterial and endotoxin translocation to mesenteric lymph nodes and other external sites, causing infectious complications [2]. Spontaneous bacterial peritonitis (SBP) is one of the most frequent complications.
The diagnosis of SBP is established when the polymorphonuclear (PMN) leukocyte count in the ascitic fluid (AF) is equal to or greater than 250 cells $/ \mathrm{mm}$, in the absence of intra-abdominal cause for infection (i.e., surgically treatable) $[3,4]$.

SBP has an estimated prevalence of $1.5-3.5 \%$ in ambulatory patients and up to $10 \%$ in hospitalized patients [5]. A prospective study reported a rate of $47 \%$ of bacterial infections in hospitalized cirrhotic patients, with $31 \%$ of these infections being SBP [6].

SBP is associated with higher mortality rates, ranging between 18 and $33 \%$ in some series [7]. Nonetheless, an early diagnosis, related to adequate therapy, allows a decrease in disease-related mortality [7].

Guidelines recommend that a diagnostic paracentesis should be performed at admission in cirrhotic patients with: (i) ascites (who require hospitalization); (ii) local or systemic symptoms (abdominal pain, tenderness, vomiting, diarrhea, hyper/hypothermia, tachycardia and/or tachypnea) (iii) signs of clinical deterioration such as hepatic encephalopathy, gastrointestinal bleeding or worsening of renal and/or liver function $[8,9]$.

Adequate handling of $\mathrm{AF}$ is required to increase the accuracy of SBP diagnosis. The injection of $1 \mathrm{~mL}$ of fluid into a purple-top ethylenediaminetetraacetic acid allows a more accurate cell count; moreover, a bedside injection of at least $10 \mathrm{~mL}$ into aerobic and anaerobic blood culture bottles increases the accuracy of positive cultures [10].

When the culture is positive (approximately $40 \%$ of cases), the most common pathogens include Gram-negative bacteria, mainly Escherichia, with Escherichia coli being the most prevalent $[5,10,11]$. Gram-positive cocci have previously accounted for less than $25 \%$ of SPB cases; however, there is a recent increased prevalence [12].

Antibiotic therapy should be initiated early to improve outcomes of disease [12]. Third-generation, broad-spectrum cephalosporins are the drugs of choice for community-acquired infections. Cefotaxime ( 2 g every $8 \mathrm{~h})$ during 5 days is considered the gold-standard therapy $[8,9$, 13]. Ceftriaxone ( $2 \mathrm{~g} /$ day for 5 days) is an acceptable alternative [14]. Albumin should be administered (1.5 g/kg at diagnosis and $1 \mathrm{~g} / \mathrm{kg}$ on day 3 ) to avoid type 1 hepatorenal syndrome [may occur in approximately $30 \%$ of SBP patients (treated with antibiotics alone)] and improve survival [8].

European guidelines suggest a new paracentesis $48 \mathrm{~h}$ after the beginning of antibiotics to demonstrate SBP resolution (by a decrease in PMN cells $>25 \%$ ) and to adjust therapy if needed [8]. However, some recent studies consider that this procedure is unnecessary for all patients 
and could be individualized according to the clinical and analytical course $[9,15]$.

With this study, the authors aim: (i) to determine the patients who may benefit from follow-up paracentesis according to clinical and analytical predictors of inadequate response on day 3 of treatment, and (ii) to create a predictor model of inadequate response to antibiotic therapy.

\section{Material and Methods}

We have performed a retrospective single-center study (in a tertiary center) including all consecutive adult patients admitted with SBP between January 2011 and June 2018. Patients who died from causes other than SBP during that period were excluded (Fig. 1).

Data from serum laboratory workup at admission and $48 \mathrm{~h}$ after the beginning of antibiotics included: blood count with platelets, cytocholestatic parameters, serum proteinogram, urea, creatinine, and C-reactive protein levels. Moreover, an initial AF evaluation was performed, simultaneously, with a differential count of fluid cells and microbiologic culture. Information regarding clinical aspects, namely abdominal pain and fever, were also collected. In all cases, antibiotics and albumin were initiated as soon as possible. Adequate antibiotic therapy response was considered when AF neutrophil count decreased more than $25 \%$ related to pretreatment value after 2 days of antibiotic treatment [8]. According to a Numerical Rating Scale, abdominal pain was felt when it was classified, by every patient, as 2 points [16]. Active alcohol consumption was defined as a consumption $\geq 20 \mathrm{~g}$ in women or $30 \mathrm{~g}$ in men. Hepatic encephalopathy was considered over 2 on the West Haven scale. Respiratory insufficiency was defined as $\mathrm{PaO}_{2}$ $<60 \mathrm{~mm} \mathrm{Hg}$. Acute kidney injury was defined according to the European Association for the Study of the Liver (EASL) criteria [8].

Statistical analysis was performed using SPSS v. $26\left(\mathrm{IBM}^{\circledR}, \mathrm{Ar}-\right.$ monk, NY, USA). Data were analyzed using a $\chi^{2}$ test for categorical variables, independent-samples $t$ test, and Mann-Whitney U nonparametric test for continuous variables. Multivariate analysis using binary logistic regression was used; the variables included as predictors were selected from univariate analysis if $p<0.1$. Model discrimination was measured using the area under the receiver operating characteristic curve (AUROC), considering 95\% confidence intervals (CIs). Statistical significance was considered if the $p$ value was less than 0.05 .

Results

\section{General Characteristics and Demographics}

We have included 96 episodes of SBP in 75 patients (79\% male sex, mean age $61 \pm 11$ years old). Demographic data are shown in Table 1 . The median time of admission was 11 days (IQR 8-19), the period corresponding to the hospital stay. In $53 \%$ of cases $(n=51)$, ceftriaxone $(2 \mathrm{~g})$ was used as initial therapy, and in 33\% $(n=32)$ piperacillin-tazobactam

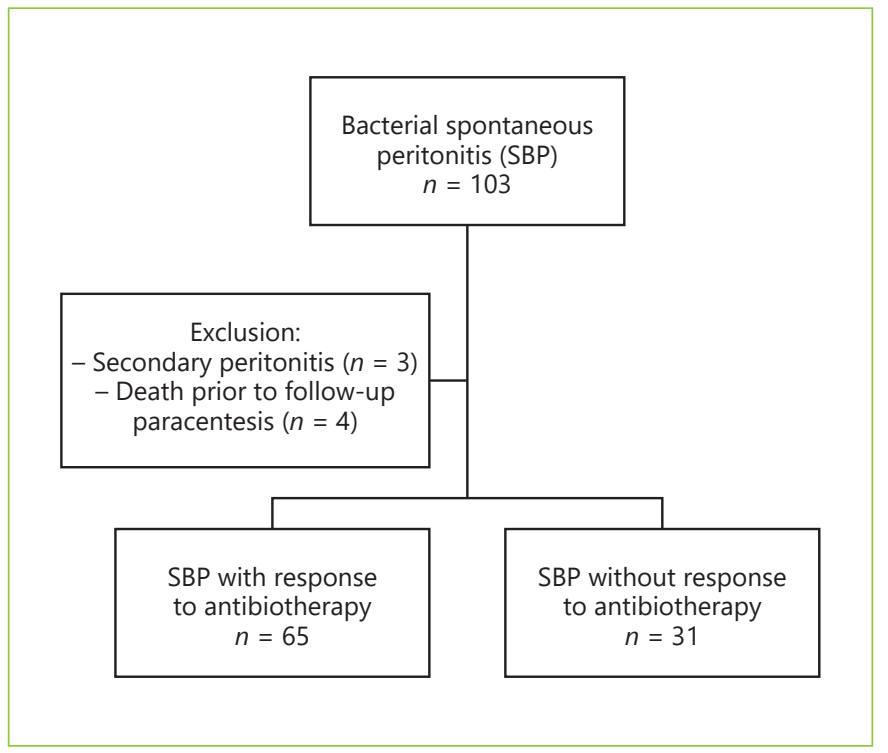

Fig. 1. Flow diagram of patient inclusion process.

(4.5 g), with renal adjustment if necessary. In $80 \%(n=77)$ of cases, the etiology of cirrhosis was alcoholic, and $83 \%$ $(n=72)$ of patients had a Child-Pugh C disease stage. Nosocomial SBP occurred in 25\% $(n=24)$ of the cases. Thirty percent of patients were on antibiotic prophylaxis with norfloxacin $(400 \mathrm{mg} /$ day $)$, and $25 \%(n=24)$ had a previous diagnosis of SBP. Sixteen percent were on rifaximin (550 $\mathrm{mg}$, twice a day) at the time of SBP diagnosis.

\section{Outcome}

An inadequate response to antibiotic therapy was observed in $30 \%$ of cases $(n=31)$ and, according to its response, patients were divided into 2 groups: those who responded to antibiotic therapy (group 1, $n=65$ ) and those without an adequate response (group $2, n=31$ ) (Table 1).

Twenty percent of patients died during admission (6 of them due to causes unrelated to peritonitis). Thirtynine percent of patients had DM, and this pathology was more prevalent in group $2(p=0.035)$.

\section{Admission}

As we can observe in Table 1, a higher median count of serum neutrophils [9.16 (5.63-11.57) vs. 6.95 (3.75$\left.9.40) \times 10^{9}, p=0.043\right]$, as well as a lower median of total proteins in AF [12 (9-16) vs. $18(11-24) \mathrm{g} / \mathrm{L}, p=0.040]$, were related to an inadequate response to therapy (group 2 ). Additionally, a positive microbiologic culture of $\mathrm{AF}$ ( $p$ $<0.001$ ) was more frequently found in this group. 
Table 1. Demographic, baseline and $48 \mathrm{~h}$ after antibiotic therapy data

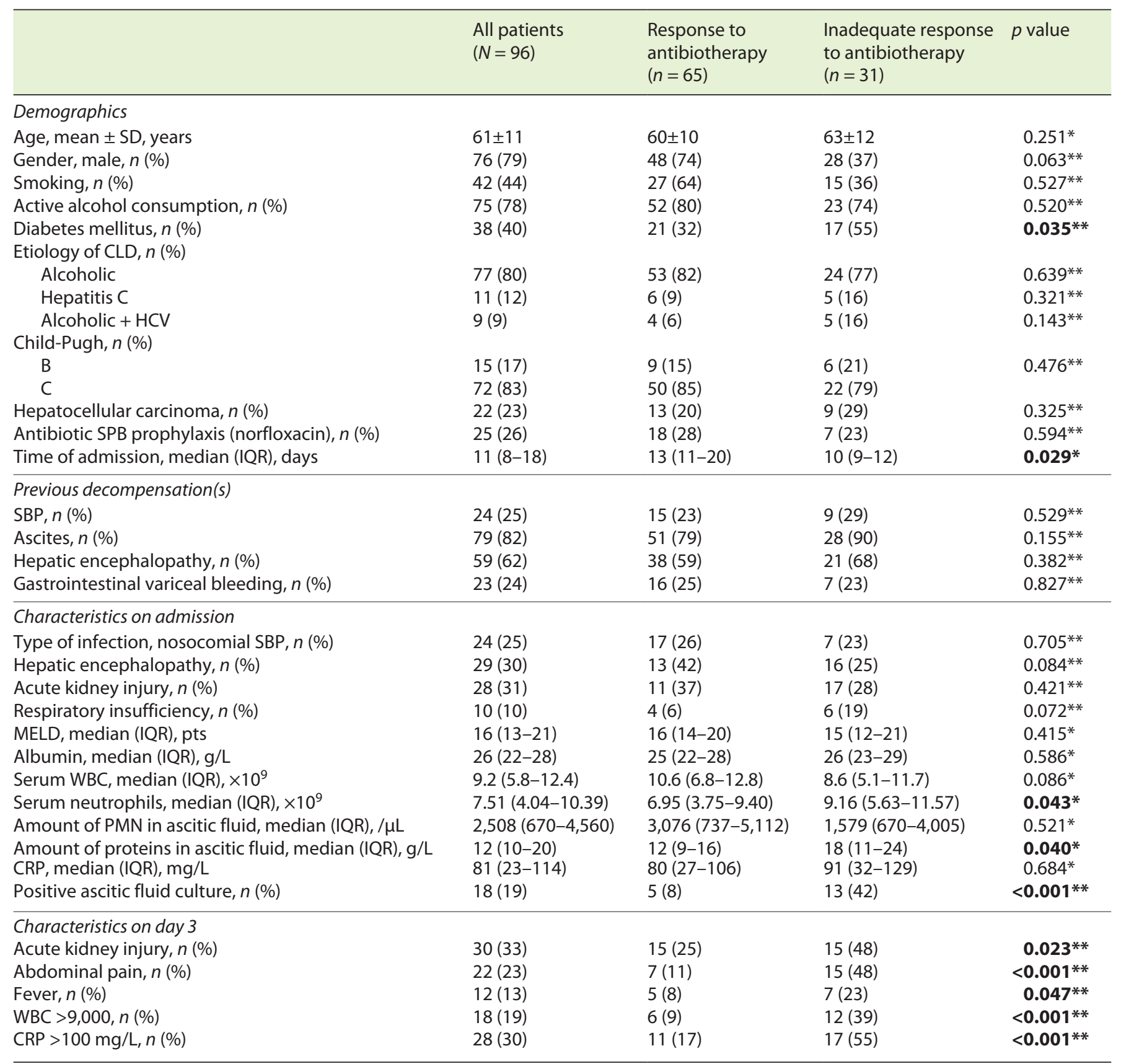

SD, standard deviation; CLD, chronic liver disease; SBP, spontaneous bacterial peritonitis; WBC, white blood cells; PMN, polymorphonuclears; CRP, C-reactive protein.

\section{Day 3 after Antibiotic Therapy}

On the 3rd day of therapy, it was observed that patients with an inadequate antibiotic response had higher counts of serum white blood cell count $(\mathrm{WBC})>9 \times 10^{9}(p<0.001)$, C-reactive protein (CRP) $>100 \mathrm{mg} / \mathrm{L}(p<0.001)$, fever $(p=$ $0.047)$ and abdominal pain $(p<0.001)$, than group 1 .

\section{Paired Analysis}

In both groups, a decrease in the serum count of leucocytes, creatinine, CRP and PMN of AF was observed. However, this decrease was more significant in patients of group 1 for PMN of AF count and serum creatinine ( $p$ $<0.001$ and $p=0.033$, respectively) (Table 2 ). 
Table 2. Variation of variables between admission and 3rd day

\begin{tabular}{|c|c|c|c|}
\hline$\Delta$ absolute serum $\mathrm{WBC}$, median (IQR), $\times 10^{9}$ & $-1.4(-5.6$ to 2.0$)$ & $-2.3(-4.9$ to -0.9$)$ & $0.071^{*}$ \\
\hline$\Delta$ absolute $\mathrm{PMN}$ of ascitic fluid, median (IQR), $/ \mu \mathrm{L}$ & $98(-230$ to 959$)$ & $-2,232(-4574$ to -490$)$ & $<0.001^{*}$ \\
\hline$\Delta \mathrm{CRP}$, median (IQR), mg/L & $14(-15.3$ to 60.8$)$ & $-9.5(-51.9$ to 6.6$)$ & $0.085^{*}$ \\
\hline$\Delta$ serum creatinine, median (IQR), $\mathrm{mg} / \mathrm{dL}$ & $0.2(-0.1$ to 0.48$)$ & $-0.1(-0.3$ to 0.1$)$ & $0.033^{*}$ \\
\hline
\end{tabular}

WBC, white blood cells; PMN, polymorphonuclears; CRP, C-reactive protein. ${ }^{*}$ Mann-Whitney U test, $p=0.05$.

Table 3. Multivariate logistic regression analysis

\begin{tabular}{|c|c|c|c|c|}
\hline \multicolumn{5}{|l|}{ Demographics } \\
\hline Age & $1.024(0.983$ to 1.067$)$ & 0.249 & $1.047(0.983$ to 1.116$)$ & 0.151 \\
\hline \multicolumn{5}{|l|}{ Gender } \\
\hline Female & Ref. & & Ref. & \\
\hline Active alcohol consumption & $0.719(0.262$ to 1.970$)$ & 0.521 & - & - \\
\hline Diabetes mellitus & $2.544(1.058$ to 6.121$)$ & 0.037 & $1.806(0.519$ to 6.283$)$ & 0.353 \\
\hline Hepatocellular carcinoma & $1.636(0.611$ to 4.383$)$ & 0.327 & - & - \\
\hline Antibiotic SPB prophylaxis (norfloxacin) & $0.762(0.280$ to 2.074$)$ & 0.594 & - & - \\
\hline Rifaximin & $0.670(0.215$ to 2.084$)$ & 0.489 & - & - \\
\hline \multicolumn{5}{|l|}{ Previous decompensation(s) } \\
\hline Gastrointestinal variceal bleeding & $0.893(0.324$ to 2.461$)$ & 0.827 & - & - \\
\hline \multicolumn{5}{|l|}{ Characteristics on admission } \\
\hline Type of infection & & & - & - \\
\hline Community-acquired & Ref. & & & \\
\hline Nosocomial & $0.824(0.301$ to 2.255$)$ & 0.706 & & \\
\hline Hepatic encephalopathy & $2.212(0.891$ to 5.493$)$ & 0.087 & $1.404(0.345$ to 5.715$)$ & 0.635 \\
\hline Acute kidney injury & 1.234 (0.501 to 3.039$)$ & 0.648 & - & - \\
\hline Respiratory insufficiency & $3.660(0.951$ to 14.091$)$ & 0.059 & 16.403 (2.315 to 116.222$)$ & 0.005 \\
\hline \multicolumn{5}{|l|}{ Characteristics on day 3} \\
\hline Acute kidney injury & $2.875(1.152$ to 7.173$)$ & 0.024 & $1.549(0.397$ to 6.041$)$ & 0.529 \\
\hline Abdominal pain & 7.768 (2.707 to 22.290$)$ & $<0.001$ & $10.381(1.807$ to 59.626$)$ & 0.009 \\
\hline
\end{tabular}

WBC, white blood cells; PMN, polymorphonuclears; CRP, C-reactive protein.

\section{Predictors of Antibiotic Failure}

In multivariate analysis, the presence of respiratory insufficiency $(\mathrm{OR}=16.403$; 95\% CI: $2.315-116.222$; $p=$ $0.005)$ and abdominal pain $(\mathrm{OR}=10.381 ; 95 \% \mathrm{CI}$ : $1.807-59.626 ; p=0.009)$ at admission, serum WBC $\geq 9$ $\times 10^{9}(\mathrm{OR}=5.832 ; 95 \% \mathrm{CI}: 1.275-26.669, p=0.023)$ and $\mathrm{CRP}>100 \mathrm{mg} / \mathrm{L}(\mathrm{OR}=5.043$; 95\% CI: 1.267-20.076; $p=0.022)$ at day $3 \mathrm{rd}$ of antibiotic therapy were predictors of an inadequate response to antibiotics in SBP (Table 3). 


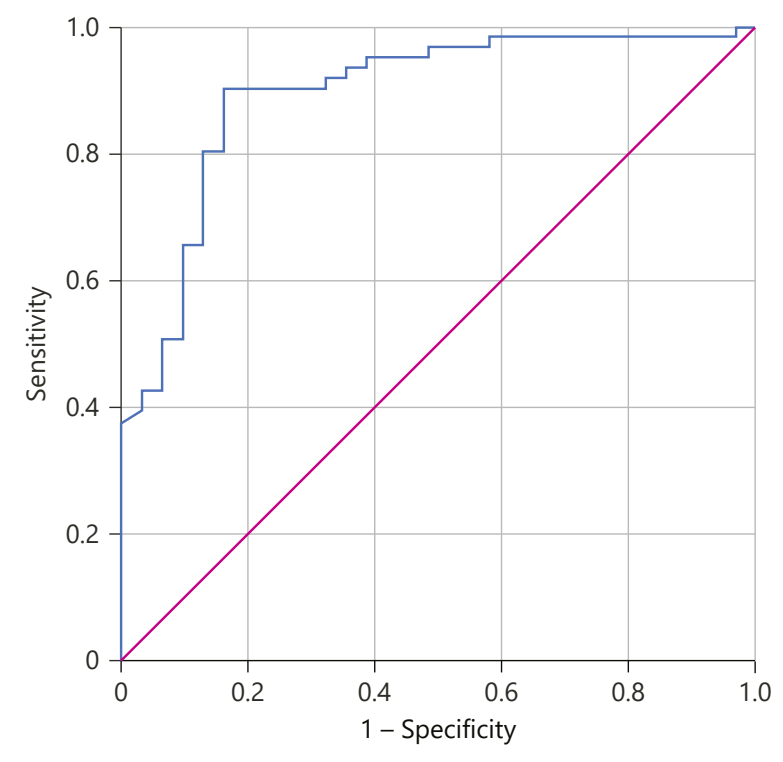

Fig. 2. ROC curve - accuracy of model in predicting inadequate response to antibiotic therapy.

A predictor model of inadequate response to therapy was created $[-3.816+(2.797 \times$ respiratory insufficiency $)$ $+(2.340 \times$ abdominal pain $)+(1.763 \times$ serum $\mathrm{WBC}>9 \times$ $\left.\left.10^{9}\right)+(1.618 \times \mathrm{CRP}>100)\right]$ with a good accuracy (AUROC $0.893, p<0.001)$; for a cut-off of 0.090 , this model has a sensitivity of $97 \%$ and a specificity of $46 \%$, with a positive predictive value of $83 \%$ and a negative predictive value of $77 \%$ (Fig. 2).

\section{Discussion}

EASL guidelines recommend an assessment of AF through a paracentesis with cytological analysis of fluid at day 3 of antibiotics for all cases of SBP to monitor response and adjust therapy, if needed [8]. In fact, in clinical practice, an intermediate analysis of AF may play an important role, namely in matters of unfavorable clinical course. It allows therapy orientation in cases of non-response and can be a clue for a specific cause for the increased count of PMN.

However, our work meets other recent studies that suggest an individualized approach when following SBP cases [9]. Moreover, this is one of the first studies in the literature that link demographic and clinical factors to the convenience (or not) of an intermediate evaluation of AF by paracentesis. By evaluating clinical and analytical parameters in patients with SBP, we could depict some factors, both at admission and on day 3 after therapy, that can predict an inadequate response to antibiotics. Furthermore, as shown in Table 2, the behavior of clinical and analytical variables between admission and patient's reevaluation corroborates this hypothesis of prediction of antibiotic therapy response.

Using previously reported variables, the authors created, for the first time in the literature, a predictive model to determine which patients can benefit from a second paracentesis to adjust antibiotic therapy (in case of inappropriate response) and to avoid dispensable invasive procedures (in patients with favorable outcomes). Therefore, our model allowed the identification, with reasonable accuracy, of individuals in whom the following paracentesis may have benefits, with a sensitivity of $97 \%$ and a negative predictive value of $77 \%$. Furthermore, if we applied this model in our population, $65 \%$ of the patients could have avoided the follow-up paracentesis, thus avoiding further complications in frail patients.

As a complication of cirrhosis, SBP tends to indicate a significant progression of the disease. This is the reason why the identification of risk factors for SBP has an essential role in evaluating the disease course [17]. In our cohort, DM was present in 39\% of patients, with a trend more prevalent in group 2. Tergast et al. [1], in their study, determined DM as a risk factor for SBP development in patients with cirrhosis due to alterations of the immune system, namely in leukocyte function, and to the polyneuropathy induced by DM. These changes lead to dyskinesia of bowel muscles and prolonged intestinal transit time, with an increased risk for bacterial translocation from the gut [18].

An interesting finding was the higher prevalence of positive AF cultures at admission in patients who did not respond to antibiotics. This fact emphasizes the role of a fine collection of AF sent to microbiologic analysis. According to the American Association for the Study of Liver Diseases (AASLD), in cases of SBP suspicion, AF should be cultured, at the bedside, in aerobic and anaerobic blood cultures bottles, prior to initiating antibiotic therapy [9]. Some studies report a higher rate of bacterial growth when AF is collected in this manner when compared to other containers (80 vs. 50\%) [15]. Therefore, a positive AF culture is an essential guide of antibiotic therapy, mainly in patients with inadequate response to empirical treatment. Moreover, we have previously reported a higher prevalence of multidrug-resistant (MDR) bacte- 
rial infections in our center, namely SBP. We believe that SBP prophylaxis with quinolones is associated with the emergence of MDR infections [17]. In our study, we only obtained a positive culture in $48 \%$ of cases, and this could be related to an inappropriate collection of $\mathrm{AF}$ at the diagnostic paracentesis. This may be considered a potential limitation of our study and could be explained by the fact that initial paracentesis was performed in the emergency department (with some limitations in AF collection). Moreover, as a retrospective study, some information about the AF collection was unclear, namely the type of culture bottle. Some other limitations of the study should be acknowledged, such as selection bias may not be avoided entirely. Therefore, prospective and multicenter studies are needed to confirm these results.

The vast majority of paracenteses occurred without complications. However, some studies reported a $10 \%$ rate of adverse events, commonly minor complications, such as the continuous outflow of AF from the puncture site or local self-limited bleeding. Nonetheless, significant events can occur, like abdominal hematoma, bleeding into the peritoneal cavity or secondary peritonitis related to visceral perforation $[9,18]$. In our study, two cases of continuous outflow of AF from the puncture site and one case of abdominal hematoma were seen.

With this study, the authors consider that clinical and analytic factors allow predicting the (un)response of antibiotic therapy. The following paracentesis should be reserved to patients with a predictable absence of response to adjust treatment. We are convinced that our results may have important implications for clinical practice and future studies.

\section{Statement of Ethics}

The study was performed according to the Declaration of Helsinki. All rules of the local ethics committee ("Comissão de Ética para a Saúde do Centro Hospitalar Universitário de São João / Faculdade de Medicina da Universidade do Porto") were followed, preserving patient identity and confidentiality.

\section{Conflict of Interest Statement}

Nothing to declare.

Funding Sources

Nothing to declare.

\section{Author Contributions}

Ana L. Santos: conception and design; analysis and interpretation of the data; drafting of the article. Rosa Coelho: critical revision of the article for important intellectual content. Marco Silva: analysis and interpretation of the data. Rui Morais: analysis and interpretation of the data; critical revision of the article for important intellectual content. Hélder Cardoso: critical revision of the article for important intellectual content. Guilherme Macedo: critical revision of the article for important intellectual content, final approval of the article.

\section{Data Availability Statement}

All data generated or analyzed during this study are included in this article. Further enquiries can be directed to the corresponding author.

\section{References}

1 Tergast TL, Laser H, Gerbel S, Manns MP, Cornberg M, Maasoumy B. Association between Type 2 Diabetes Mellitus, HbA1c and the Risk for Spontaneous Bacterial Peritonitis in Patients with Decompensated Liver Cirrhosis and Ascites. Clin Transl Gastroenterol. 2018 Sep;9(9):189.

2 Tsiaoussis GI, Assimakopoulos SF, Tsamandas AC, Triantos CK, Thomopoulos KC. Intestinal barrier dysfunction in cirrhosis: current concepts in pathophysiology and clinical implications. World J Hepatol. 2015 Aug;7(17):2058-68.

3 Hoefs JC, Canawati HN, Sapico FL, Hopkins RR, Weiner J, Montgomerie JZ. Spontaneous bacterial peritonitis. Hepatology. 1982;2(4): 399-407.

4 van de Geijn GJ, van Gent M, van Pul-Bom N, Beunis MH, van Tilburg AJ, Njo TL. A new flow cytometric method for differential cell counting in ascitic fluid. Cytometry B Clin Cytom. 2016 Nov;90(6):506-511.

5 Rimola A, García-Tsao G, Navasa M, Piddock LJ, Planas R, Bernard B. Diagnosis, treatment and prophylaxis of spontaneous bacterial peritonitis: a consensus document. Int Ascites Club J Hepatol. 2000;32:142-53.

6 Caly WR, Strauss E. A prospective study of bacterial infections in patients with cirrhosis. J Hepatol. 1993 Jul;18(3):353-8.

7 Niu B, Kim B, Limketkai BN, Sun J, Li Z, Woreta $\mathrm{T}$, et al. Mortality from Spontaneous Bacterial Peritonitis Among Hospitalized Patients in the USA. Dig Dis Sci. 2018 May;63(5):1327-33.

8 Angeli P, Bernardi M, Villanueva C, Francoz C, Mookerjee RP, Trebicka J, et al; European Association for the Study of the Liver. EASL Clinical Practice Guidelines for the management of patients with decompensated cirrhosis. J Hepatol. 2018 Aug;69(2):406-60.
9 Runyon BA; AASLD Practice Guidelines Committee. Management of adult patients with ascites due to cirrhosis: an update. Hepatology. 2009 Jun;49(6):2087-107.

10 Dever JB, Sheikh MY. Review article: spontaneous bacterial peritonitis-bacteriology, diagnosis, treatment, risk factors and prevention. Aliment Pharmacol Ther. 2015 Jun;41(11):1116-31.

11 Fernández J, Acevedo J, Castro M, Garcia O, de Lope CR, Roca D, et al. Prevalence and risk factors of infections by multiresistant bacteria in cirrhosis: a prospective study. Hepatology. 2012 May;55(5):1551-61.

12 Piroth L, Pechinot A, Di Martino V, Hansmann Y, Putot A, Patry I, et al. Evolving epidemiology and antimicrobial resistance in spontaneous bacterial peritonitis: a two-year observational study. BMC Infect Dis. 2014 May;14(1):287. 
13 Alves De Mattos A, Micheli Costabeber A, Ca-Prara Lionço L, Tovo CV, Lionço LC. Multi-resistant bacteria in spontaneous bacterial peritonitis: A new step in management? World J Gastroenterol. 2014;20(39):1407986.

14 Mazer L, Tapper EB, Piatkowski G, Lai M. The need for antibiotic stewardship and treatment standardization in the care of cirrhotic patients with spontaneous bacterial peritonitis - a retrospective cohort study examining the effect of ceftriaxone dosing. F1000 Res. $2014 \mathrm{Feb} ; 3: 57$.
15 MacIntosh T. Emergency Management of Spontaneous Bacterial Peritonitis - A Clinical Review. Cureus. 2018 Mar;10(3):e2253.

16 Tandon M, Singh A, Saluja V, Dhankhar M, Pandey CK, Jain P. Validation of a new "objective pain score" vs. "Numeric rating scale" for the evaluation of acute pain: A comparative study. Anesth Pain Med. 2016 Jan;6(1):e32101.
17 Stepanova M, Rafiq N, Younossi ZM. Components of metabolic syndrome are independent predictors of mortality in patients with chronic liver disease: a population-based study. Gut. 2010 Oct;59(10):1410-5.

18 Triantafyllou K, Kalantzis C, Papadopoulos AA, Apostolopoulos P, Rokkas T, Kalantzis $\mathrm{N}$, et al. Video-capsule endoscopy gastric and small bowel transit time and completeness of the examination in patients with diabetes mellitus. Dig Liver Dis. 2007 Jun;39(6):57580. 